\title{
BioLink
}

Jurnal Biologi Lingkungan, Industri, Kesehatan

Available online http://ojs.uma.ac.id/index.php/biolink

\section{BIOECOLOGY OF GIANT FRESHWATER PRAWNS (MACROBRACHIUM ROSENBERGII) IN THE BILAH RIVER, LABUHANBATU DISTRICT, NORTH SUMATERA}

\author{
Siti Aminah Nasution, Rivo Hasper Dimenta* \\ Department of Biology Education, Faculty of Teacher Training and Education, Universitas \\ Labuhan Batu, Indonesia
}

Submited : 04-05-2021; Reviewed :16-06-2021; Accepted : 11-01-2022

*Corresponding author: E-mail : $\underline{\text { rivohd11@gmail.com }}$

\begin{abstract}
Giant freshwater prawns (Macrobrachium rossenbergii) were still been the favorite prawn catch of local fishermen in the Labuhanbatu district. This raises concerns for the survival of these animals. Therefore, it is necessary to conduct a study to obtain bioecological information on this giant freshwater, giant prawns in the Bilah river especially inform about condition the abundance based on gonad maturity levels, and the growth patterns of Giant freshwater prawns (M. rossenbergii). This study was conducted at 3 stations around the Bilah river. These stations were determined using a purposive sampling method. Furthermore, sampling was carried out using fishing nets. After that, the caught fish were analyzed to find out the Fulton's condition factor, the abundance of prawns based on gonad maturity levels, and the growth patterns. The results of growth patterns analysis which calculate from the relationship of carapace length and body weight of $M$. rossenbergii caught were showed negative allometric category ( $b$ value 1.88 to 2.577). Meanwhile, the abundance of giant freshwater prawns based on gonad maturity levels for males and females were dominated by immature prawns (ranging from 46.15 to $54.65 \%$ ).
\end{abstract}

Keywords: Fulton Condition factor; Giant freshwater prawns; Growth patterns; Gonad maturity levels; Macrobrachium rossenbergii

How to Cite: Nasution, S.A. \& Dimenta, R.H. (2022). Bioecology Of Giant Freshwater Prawns (Macrobrachium Rosenbergii) In The Bilah River, Labuhanbatu District, North Sumatera, BioLink: Jurnal Biologi Lingkungan, Industri dan Kesehatan, Vol. 8 (2): Hal. 132-144 


\section{INTRODUCTION}

Giant freshwater prawns are crustacean freshwater from the Palaemonidae family, in which this species has the largest size compared to other freshwater shrimp (Indarjo et al., 2011; Monica et al., 2017). Giant freshwater prawns live in two habitats, namely freshwater and brackish water. In the larval stage, Diana et al., (2018) inform these prawns live in brackish water, However, they go to freshwater from the juvenile stage until the adult stage.

According to Indarjo et al., (2021) the special characteristic of giant freshwater prawns is having the rostrum with $11-15$ serrations on the upper part and $8-14$ serrations on the lower part. Furthermore, the rostrum is long and has a sword-like shape. On the body or abdomen, these prawns have five segments. Each of them is equipped with swimming legs (pleopods). Meanwhile, on the chest, they have five pairs of walking legs (periopods). Suwartiningsih \& Utami (2020) explained that Adult of male prawns have the second walking leg that is larger in length than the other legs, up to 1.5 times the length of the body. Meanwhile, in females, the difference in their leg size is not striking. On the female prawns, the in-between of the swimming legs are slightly wider and form a room to incubate the eggs. Giant freshwater prawns have 11 stages of life which last 40 days. They are morphologically shaped as their natural habitat, making them like to walk on the riverbed for finding food and moving from the brackish water to the freshwater environment.

Due to their relatively large size compared to other fresh prawn species, giant freshwater prawns have high economic value, making the demand for these prawns always high. Furthermore, these prawns have many advantages, such as fast growth, large body size, and having domestic and export market opportunities. Therefore, it highly depends on the catch in nature (Suwartiningsih \& Utami, 2020; Setijaningsih et al., 2019). The price of giant freshwater prawns in the Indonesian market ranges from $150,000-200,000$ IDR $/ \mathrm{kg}$. Meanwhile, the price from the prawn farmers is around 57,000 - 60,000 IDR/kg (Wahyudi \& Fadlil, 2013; Suwartiningsih \& Utami, 2020). The superior parent of these prawns can be obtained through genetic improvement. Therefore, it requires morphological characteristics of the prawns that are considered superior for the genetic improvement of giant freshwater prawns (Indarjo et al., 2021; Suwartiningsih \& Utami, 2020).

Environmental factors that affect the distribution of aquatic animals are closely related to $\mathrm{pH}$ level, temperature, oxygen, 
alkalinity, calcium, sodium, and potassium found in the area (Indarjo et al., 2021; Manurung et al., 2018). Therefore, giant freshwater prawns (M. ronsenbergii) are not found in the upstream part of the river because the location has very low salinity (Ipandri et al., 2016; Suwartiningsih \& Utami, 2020). Furthermore, Wijaya \& Muchtar (2019) explain that the distribution of freshwater prawns is influenced by the presence of brackish and freshwater phases during their life cycle. In addition, they have a very wide geographical distribution ranging from Africa to French-Polynesia, including Indonesia.

Studies related to these prawns have been conducted such as, Harahap (2020) studied the aspect of the reproductive biology of these prawns in the Barumun river, South Labuhanbatu; Aini et al., (2018) inform about the development stage of larvae these prawns in Aceh and Stanin Siratu. Litavia et al. (2019) conducted identification of these prawns found in the swamp around the Riau's Stadion, Pekanbaru. Syatriawan et al., (2019) reported the cultivation of these prawns. Furthermore, Sofian \& Sari (2018); Ali \& Waluyo (2015) informed about the growth pattern in the Ogan river, South Sumatra.

Community activities around the river, intensive traditional fishing in various ways, local community settlements, domestic waste disposal, and environmental factors, such as decreased water quality, become the main causes of the decline in the giant freshwater prawn population (Indarjo et al., 2011; Permana et al., 2018). Based on the elaboration above, the aforementioned factors are considered to impact the population of giant freshwater prawns (M. rosenbergii) in the future around the estuary of the Bilah river. Therefore, it is necessary to study the population abundance, growth patterns, and gonad maturity levels of these prawns found around the estuary of the Bilah river.

\section{MATERIALS AND METHODS}

This study was conducted at the estuary of the Bilah river, administratively located in Panai Hilir District, Labuhananbatu, from December 2020 to February 2021. There were 3 research stations in this study. They were determined using the purposive sampling method. Station 1 was located in the area of Pangkatan District with the ordinate point at $2^{\circ} 27^{\prime} 29.06^{\prime \prime} \mathrm{N}$ and $100^{\circ} 4^{\prime} 20.32^{\prime \prime} \mathrm{E}$. Furthermore, Station 2 was located in the area of Sei Jawi - Jawi with the ordinate point at $2^{\circ} 29^{\prime} 28.95^{\prime \prime} \mathrm{N}$ and $100^{\circ} 06^{\prime} 27.56^{\prime \prime}$ E. In addition, Station 3 was located in the area of Sei Berombang with the ordinate point at $2^{\circ} 30^{\prime} 31.03^{\prime \prime} \mathrm{N}$ and $100^{\circ} 08^{\prime} 7.12^{\prime \prime} \mathrm{E}$. The tools used in this study were 
GPS (Global Positioning System), digital length of $\pm 60 \mathrm{~m}$, net height of $3-5 \mathrm{~m}$, and scales, millimeter paper, digital cameras, mesh size of 2.5 inches). rulers, flashlights, and fishing nets (net

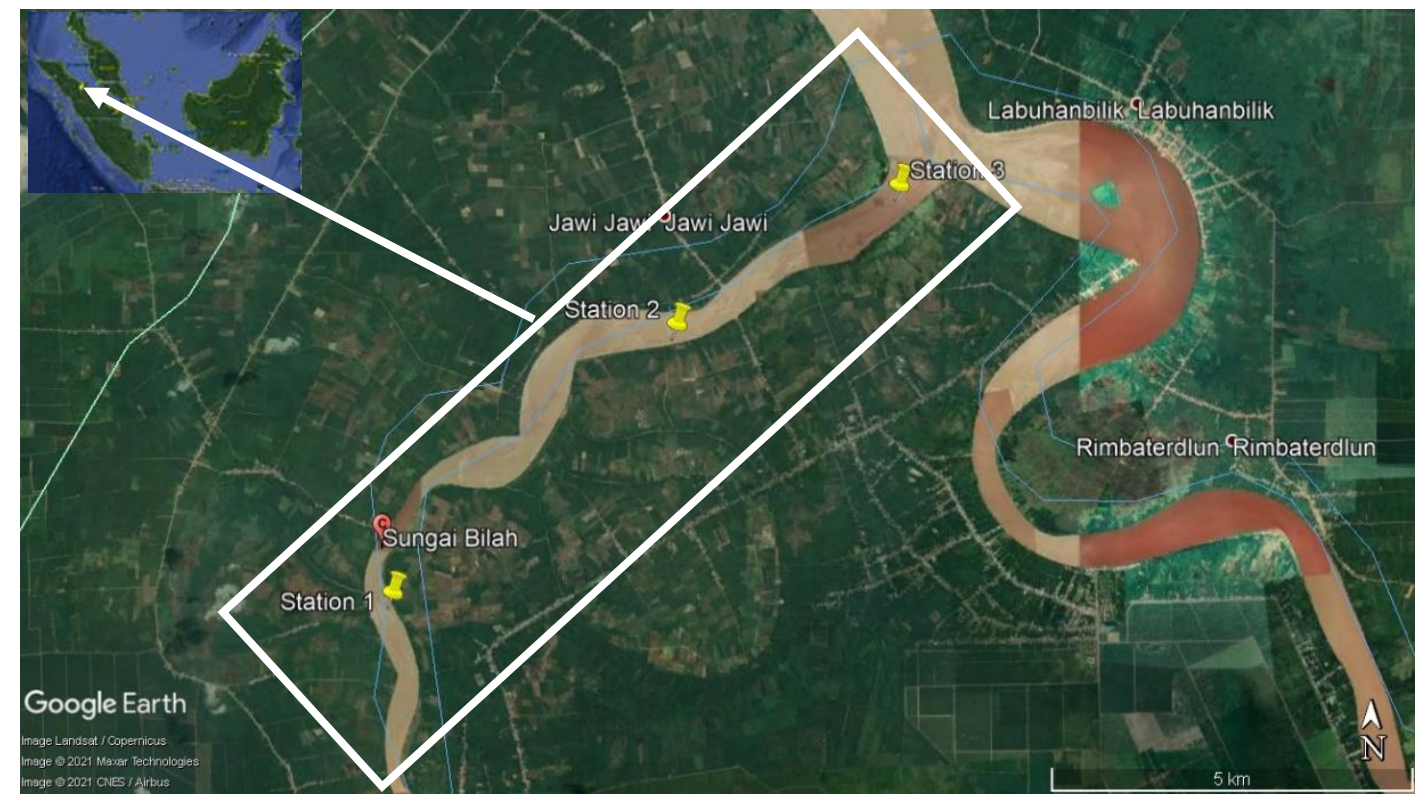

Figure 1. The Map of Research Location

\section{Research Procedure}

Samples in this study were giant freshwater prawns ( $M$. rosenbergii) caught using fishing nets. The caught prawns were measured for their morphometry, such as total length, carapace length, and body weight. After that, it was followed by the observation of these caught prawns.

Sampling was carried out at low tide and night on the riverbank with the mangrove ecosystem around the Bilah river. Furthermore, the procedures carried out were the morphometric measurement using calipers and the weight measurement using digital scales. The analysis result of the growth pattern of these prawns was presented descriptively by analyzing the length-weight relationship of these prawns.

The observation on gonad maturity levels was carried out by observing the morphology of the gonads in low light conditions using a flashlight directed at the prawns' bodies. The description of gonad maturity levels refers to Dimenta (2013); Safitri et al. (2019) (seen in Table 1). 
Table 1. Criteria of Gonad Maturity Levels for Giant Freshwater Prawns M. ronsenbergii

\begin{tabular}{ll}
\hline Gonad Maturity Levels & The Description of Macroscopic Characteristics \\
\hline Level 1 & The ovary line appears blackish green. At the end of this stage, \\
the line is clear and appears to be elongated in the dorsal \\
cephalothorax. \\
The color of the ovary is getting thicker and clearer. The \\
yellow color appears under the carapace. At the end of this \\
stage, the shape and color are progressively expanding \\
towards the back of the rostrum. \\
The color of the ovary is dark yellow and the volume increases \\
towards the side of the cephalothorax. At the end of this stage, \\
the color changes to orange-red. \\
The color of the ovary is orange and the volume increases to \\
the tip of the rostrum near the eye.
\end{tabular}

\section{Data Analysis}

\section{The Abundance Based on Gonad Maturity Levels}

The abundance of giant freshwater prawns (M. rosenbergii) individually and their abundance based on the gonad maturity levels can be found out using the equation proposed by Dimenta (2013), as follows.

$$
K=\frac{n}{A}
$$

Where:

$\mathrm{K}$ : the abundance of individuals or abundance based on size class (ind $/ \mathrm{m}^{2}$ )

$\mathrm{n}$ : the total of prawns individually or based on size class (ind)

A : the total area of the fishing net $\left(20.25 \mathrm{~m}^{2}\right)$

\section{Growth Patterns}

The obtained data included the total of caught prawns, the total length of prawns $(\mathrm{cm})$, the weight of prawns (grams), and the food composition of the prawns. Growth patterns were analyzed using the length-weight relationship.
According to Sofian \& Sari (2018), the formula for the length-weight relationship is as follows.

$$
\mathbf{W}=\mathbf{a} \mathbf{L}^{\mathbf{b}}
$$

Where,

$$
\begin{array}{ll}
\text { W } & \text { : weight }(\mathrm{g}), \\
\mathrm{L} & \text { : length }(\mathrm{cm}),
\end{array}
$$

a dan $\mathrm{b}$ : constants

The equation above is then converted into a logarithmic form so that it becomes a linear equation as follows.

\section{$\log W=\log a+b \log L$}

To test the significance level of the value of $b$, the T-test must be carried out. Interpretation by Simon et al., (2014); and Seiyaboh et al., (2016) which describe if the value of $b$ is equal to $3(b=3)$ the lengthweight relationship is isometric, meaning that the length and weight of prawn are balanced. Conversely, if $\mathrm{b}$ is not equal to 3 $(b \neq 3)$, the length-weight relationship is allometric. Furthermore, if $\mathrm{b}$ is lower than $3(b<3)$ it indicates a negative allometric, 
meaning that the length of giant prawns is more dominant than their weight. However, if the value of $b$ is higher than 3 (b>3) it indicates a positive allometric, meaning that the weight of giant prawns is more dominant than their length.

\section{Condition factors}

There are two types of condition factors analyzed in this study, namely the relative weight condition factor and Fulton's condition Factor. The relative weight condition factor is calculated using Pratiwi \& Dimenta (2021) equation, as follows.

$$
\mathrm{Wr}=(\mathrm{Wt} / \mathrm{Ws}) \times 100
$$

Where: $\mathrm{Wr}$ is relative weight; $\mathrm{Wt}$ is the weight of each sample; Ws is the prediction of the standard weight of the same sample as it is calculated from the combined length-weight regression over the range between species using the equation of Ws $=a L^{b}$.

Meanwhile, Fulton's $\mathrm{K}$ condition factor is calculated based on Fulton's equation from Pratiwi \& Dimenta (2021), as follows.

$$
\mathrm{K}=\mathrm{W} \cdot \mathrm{L}-3 \times 100
$$

Where: $\mathrm{K}$ is the condition factor; $\mathrm{W}$ is the weight (g); $\mathrm{L}$ is the length ( $\mathrm{mm}) ;-3$ is the length coefficient to test whether the $\mathrm{K}$ value tends to be close to 1 .
RESULTS AND DISCUSSION

\section{Condition Factors of Biological Parameters of $M$. rosenbergii}

Based on the results of the analysis on Bilah river, the male giant freshwater prawns (M. rosenbergii) were obtained total length (TL) ranged from $9.70-25.30$ $\mathrm{cm}$ with an average of $15.77 \mathrm{~cm}$ and with weight (W) ranged from 24.18 - 202.18 grams with an average of 63.87 grams. The weight prediction (Ws) ranged from 22.42 - 141.72 grams with an average of 59.61 grams. The relative weight $(\mathrm{Wr})$ ranged from 55.04 - 150.07 grams with an average of 103.79 grams. Furthermore, Fulton's K condition factor ranged from $0.57-2.83$ with an average of 1.98 .

Meanwhile, based on the results of the analysis on the female giant freshwater prawns, the obtained total length (TL) ranged from $11.30-27.20 \mathrm{~cm}$ with an average of $17.31 \mathrm{~cm}$. The weight (W) ranged from 36.17 - 312.47 grams with an average of 91.44 grams. The weight prediction (Ws) ranged from $26.44-221.58$ grams with an average of 84.18 grams. The relative weight (Wr) ranged from 66.49 - 192.85 grams with an average of 58.29 grams. 
Table 2. Biological parameters of $M$. ronsenbergii at the Estuary of the Bilah River

\begin{tabular}{lllll}
\hline Parameters & Males & Average & Females & Average \\
\hline Total length, TL (cm) & $9.70-25.30$ & 15.77 & $11.30-27.20$ & 17.31 \\
Weight, W (gram) & $24.18-202.18$ & 63.87 & $36.17-312.47$ & 91.44 \\
Weight Prediction, Ws (grams) & $22.42-141.72$ & 59.61 & $26.44-221.58$ & 84.18 \\
Relative Weight, (Wr) & $55.04-150.07$ & 103.79 & $66.49-192.85$ & 58.29 \\
Fulton's condition factor, (K) & $0.57-2.83$ & 1.98 & $0.59-3.67$ & 2.64 \\
$\begin{array}{l}\text { The coefficient of determination } \\
\left(\mathrm{r}^{2}\right)\end{array}$ & 0.796 & - & 0.823 & - \\
The value of $b$ & & - & & - \\
\hline
\end{tabular}

Furthermore, Fulton's K condition factor ranged from $0.59-3.67$ with an average of 2.64. Hargiyatno et al. (2013) in their study on the Palaemonidae family (in the same family with $M$. rosenbergii) reported the results of morphometric measurements of lobsters (Panulirus homarus) in the waters of Yogyakarta and Pacitan. They obtained that the relative weight (Wr) of male lobsters ranged from 58.5 - 166.9 grams with an average of 99.5 grams and Fulton's $\mathrm{K}$ condition factor ranged from $0.658-0.658$ with an average of 0.9. In addition, they also obtained that the relative weight (Wr) of female Panulirus homarus ranged from 61.7 143.5 grams with an average of 101.9 grams and Fulton's $\mathrm{K}$ condition factor ranged from $0.804-1.074$ with an average of 1.003 . The average relative weight and the condition factor for male Panulirus homarus are smaller than that of females. The value of the condition factor seems to decrease as the size of the carapace increases.

\section{Growth Patterns of Giant Freshwater Prawns (M. rosenbergii)}

The results of the analysis of the relationship between carapace length and body weight of giant freshwater prawns indicated that the obtained $b$ value at Station 1 was 1.880 . This value of $b$ illustrates the growth pattern of giant freshwater prawns through the linear equation. In this study, the body weight and the length of the carapace from each giant freshwater prawn caught from the Bilah river were measured. The results of the growth pattern calculation of giant freshwater prawns found at Station 1 (can be seen in Figure 2).

The results of the analysis of the relationship between carapace length and body weight of giant freshwater prawns indicated that the obtained $b$ value at Station 2 was 2.354. This value of $b$ illustrates the growth pattern of giant freshwater prawns through the linear equation. In this study, the body weight and the length of the carapace from each giant freshwater prawn caught from the 
Nasution, S.A. \& Dimenta, R.H. Bioecology Of Giant Freshwater Prawns (Macrobrachium Rosenbergii) In The Bilah River, Labuhanbatu District, North Sumatera

Bilah river were measured. The results of freshwater prawns found at Station 2 (can the growth pattern calculation of giant be seen in Figure 3).

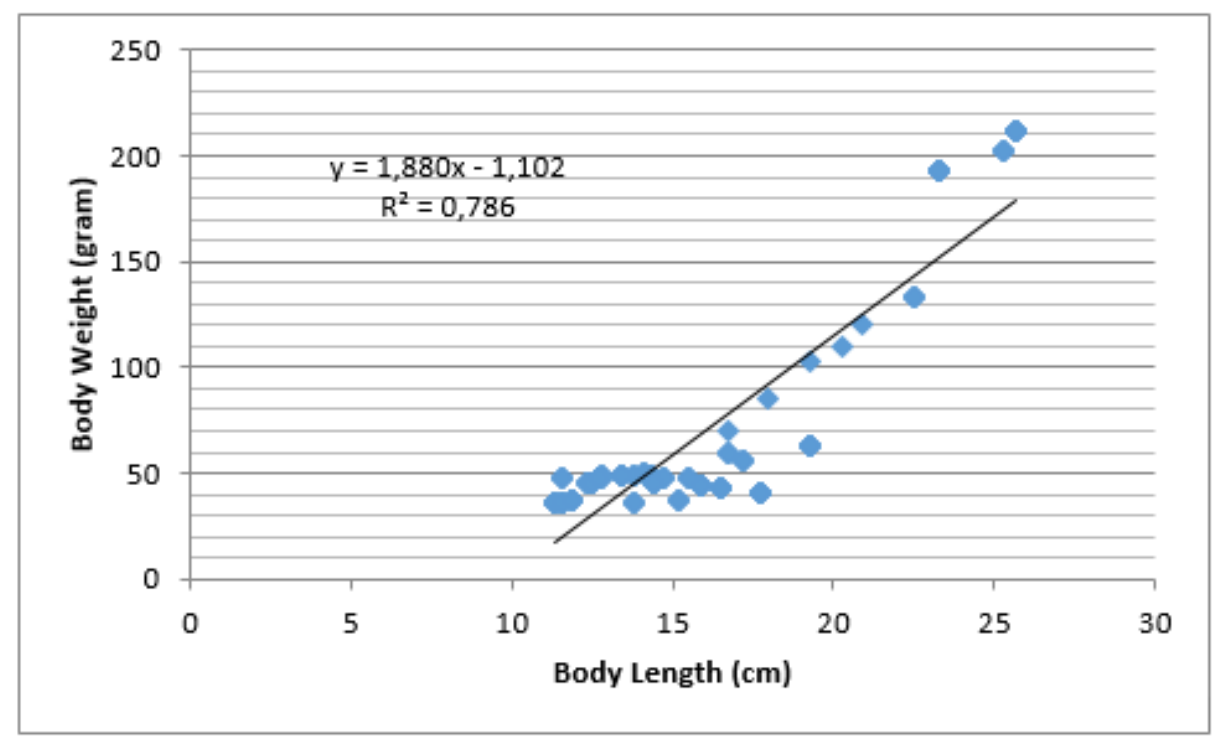

Figure 2. The Graph of the Length - Weight Relationship of Giant Freshwater Prawns (M. rosenbergii) at Station 1

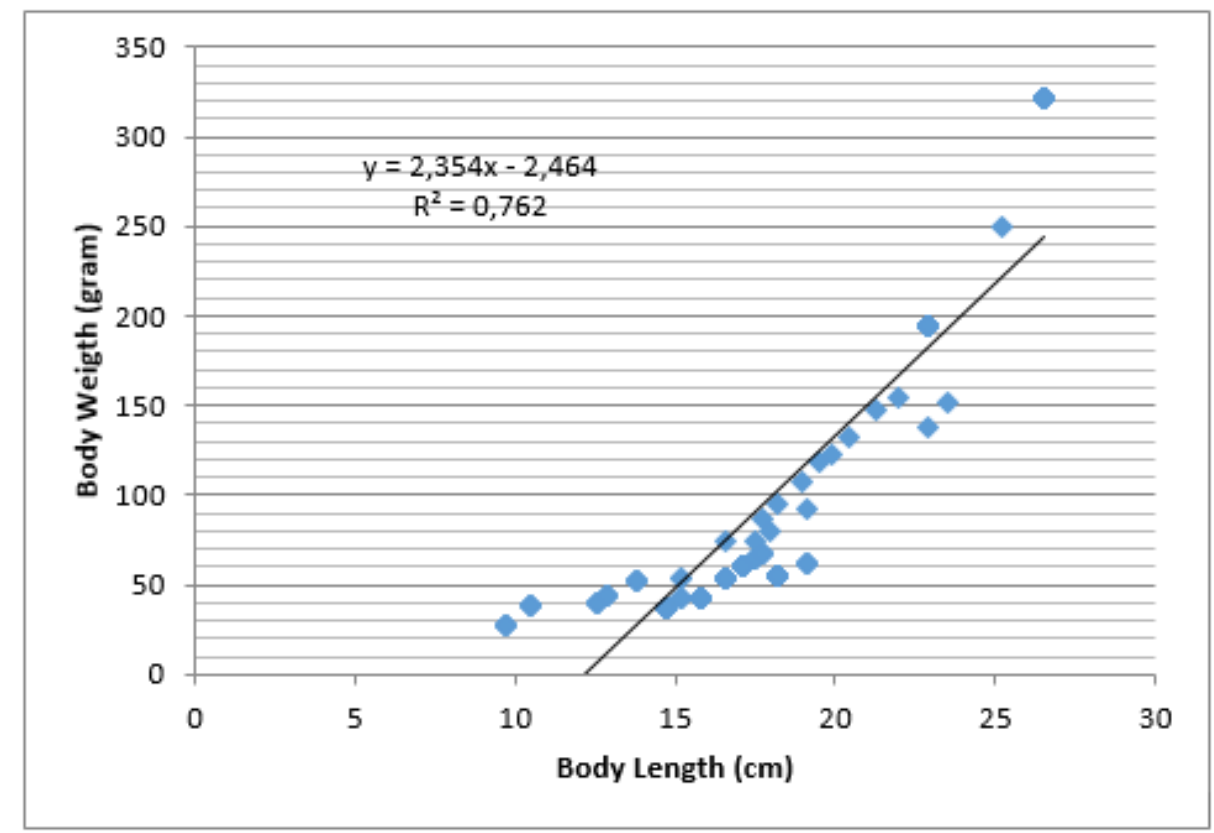

Figure 3. The Graph of the Length - Weight Relationship of Giant Freshwater Prawns (M. rosenbergii) at Station 2 


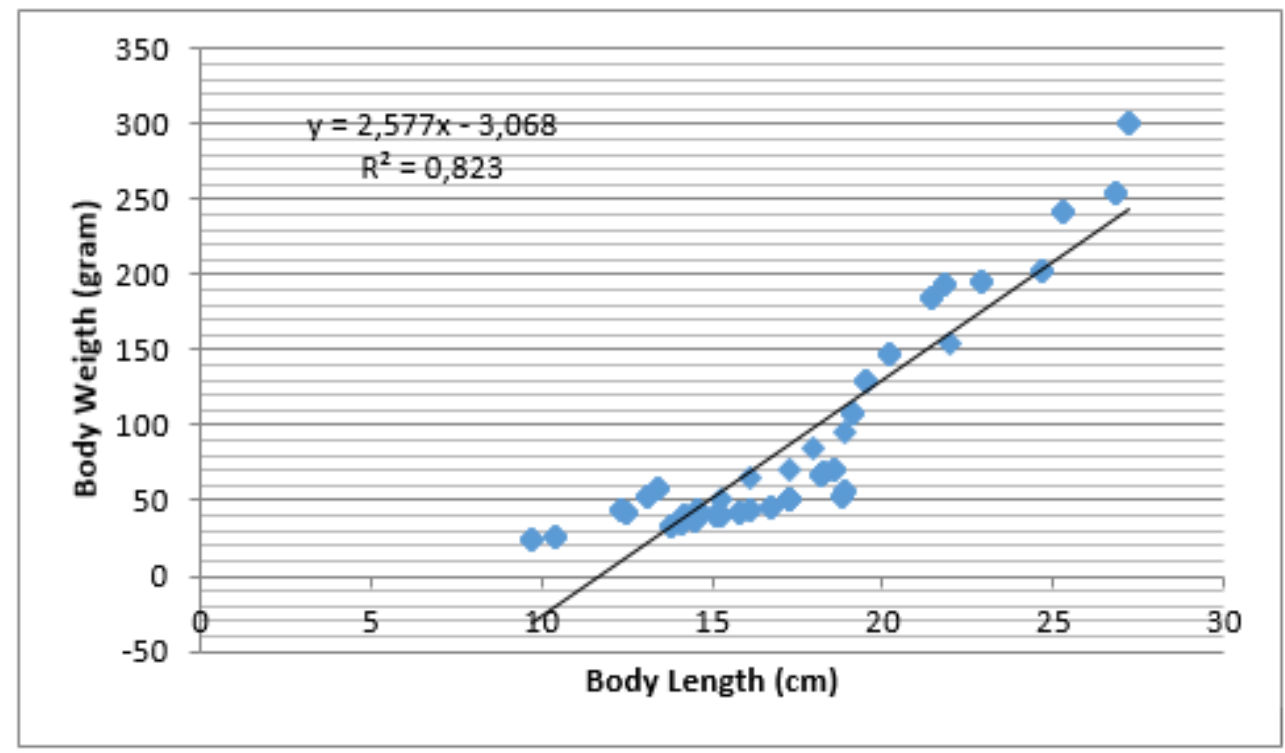

Figure 4. The Graph of the Length - Weight Relationship of Giant Freshwater Prawns (M. rosenbergii) at Station 3

The results of the analysis of the relationship between carapace length and body weight of giant freshwater prawns indicated that the obtained $b$ value at Station 3 was 2.577. This value of $b$ illustrates the growth pattern of giant freshwater prawns through the linear equation. In this study, the body weight and the length of the carapace from each giant freshwater prawn caught from the Bilah river were measured. The results of the growth pattern calculation of giant freshwater prawns found at Station 3 (can be seen in Figure 4).

The highest growth pattern was found at Station 3 which is located in the area of Sei Berombang in which the obtained $b$ value of $B$ was 2.577. This value was lower than $(b<3)$, meaning that giant freshwater prawns at Sei Berombang, Labuhanbatu have a negative allometric growth pattern. In other words, the growth in length is faster than the growth in weight. According to Syatriawan et al., (2019); Waluyo et al., (2019); Monica et al., (2017), the length growth of prawns is balanced with the weight growth if the obtained b value is equal to 3 , which is then called isometric. However, if the $b$ value is greater or less than 3 , it is called allometric, with the assumptions that if $b$ value is $<3$, it means that the growth in length is faster than the growth in weight and if the $b$ value is $>3$, it means that the growth in weight is faster than the growth in length.

In this study, the results showed that all observation stations have $b$ values of $<3$. In addition, the table concerning the growth pattern calculation showed that the highest $b$ coefficient value was obtained in Station 3 was 2.577. 
Meanwhile, the lowest b coefficient value was obtained in station 1 was 1.880 . From the data obtained from each station, it can be concluded that the relationship between carapace length and body weight has a negative allometric growth pattern, meaning that the growth in length is faster than the growth in weight $(b<3)$ (Waluyo et al., 2019; Manurung et al., 2018; Monica et al., 2017). In other words, the body weight gain is slower than the increase of carapace length. Therefore, the caught prawns were in the thin category. This can be seen from the giant freshwater prawns caught at each station which are generally small to medium-sized.

\section{The Abundance of Gonad Maturity} Levels $M$. rosenbergii in Bilah river

The results of the abundance in male giant freshwater prawns (see Figure 5) found at the estuary of the Bilah river indicated that they were dominated by giant freshwater prawns with the immature gonad category (54.65\%), having sizes ranging from 7.5 to $12.5 \mathrm{~cm}$. Furthermore, the percentage abundance of the caught prawn categorized in the gonad maturity level 1 was $22.10 \%$ with sizes ranging from 11.25 to $13.75 \mathrm{~cm}$. In addition, the percentage of the caught prawn categorized in the gonad maturity level 2 was $13.95 \%$ with sizes ranging from 12.5 to $15.0 \mathrm{~cm}$. On top of that, the percentage of the caught prawn categorized in the gonad maturity level 3 was $6.97 \%$, and that in gonad maturity level 4 was $2.33 \%$ with sizes of prawn from these two levels ranging from 12.5 to $15.0 \mathrm{~cm}$.

analysis based on the gonad maturity level

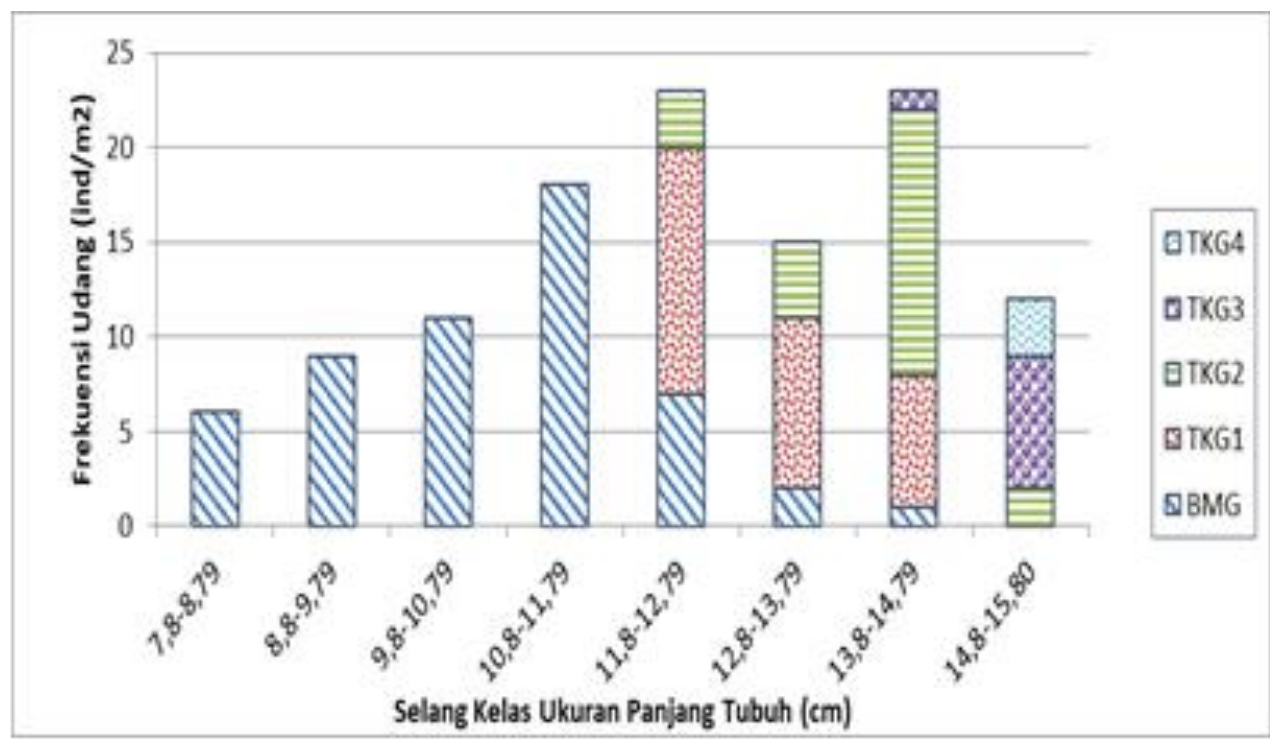

Figure 5. The Abundance of Male Giant Freshwater Prawns (M. rosenbergii) Found at the Estuary of the Bilah River Based on Gonad Maturity Levels 


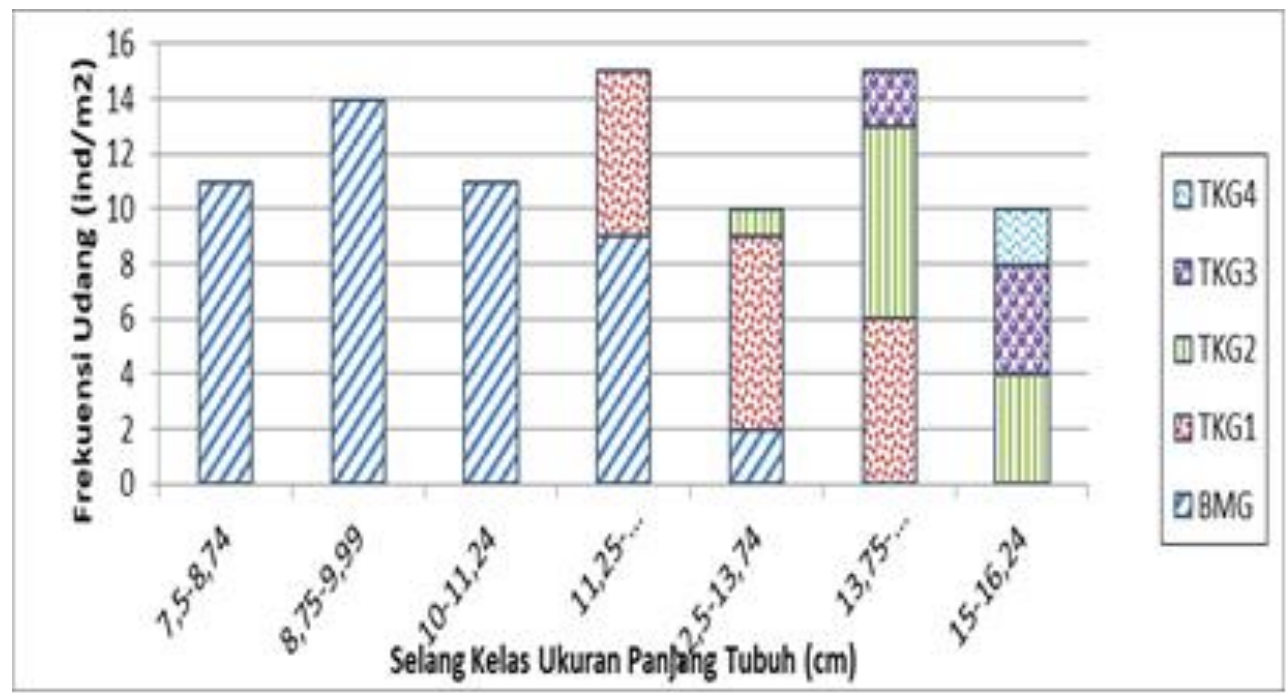

Figure 6. The Abundance of Female Giant Freshwater Prawns (M. rosenbergii) Found at the Estuary of the Bilah River Based on Gonad Maturity Levels

Meanwhile, the results of the abundance analysis based on the gonad maturity level in female giant freshwater prawns (see Figure 6.) found at the estuary of the Bilah river indicated that they were also dominated by giant freshwater prawns with the immature gonad category (46.15\%), having sizes ranging from 7.8 to $11.8 \mathrm{~cm}$.

Furthermore, the percentage of the caught prawn categorized in the gonad maturity level 1 was $24.78 \%$ with sizes ranging from 11.8 to $13.8 \mathrm{~cm}$. In addition, the percentage of the caught prawn categorized in the gonad maturity level 2 was $19.66 \%$ with sizes ranging from 11.8 to $14.8 \mathrm{~cm}$. On top of that, the percentage of the caught prawn categorized in the gonad maturity level 3 was $6.84 \%$, and that in gonad maturity level 4 was $2.56 \%$ with sizes of prawn from these two levels ranging from 14.8 to $15.8 \mathrm{~cm}$.
The abundance of giant freshwater prawns (M. rosenbergii) caught during this study is presented in Figures 6 and 7. Based on field observations, it is found out that the total of caught female prawns is more than that of caught male prawns $258 \mathrm{ind} / \mathrm{m}^{2}$ for males and 351 ind $/ \mathrm{m}^{2}$ for females. This condition were describe the prediction that the abundance of $M$. rosenbergi stock population of female prawn were highest value for next period of prawn caught.

The abundance of $M$. rosenbergii population around the estuary of the Bilah river based on the gonad maturity levels when this study was conducted from December 2020 to February 2021, they were dominated by prawns with the immature gonad category. Furthermore, the lowest abundance was found at prawns with the gonad maturity level 4 . This means that the giant freshwater prawns when this study was conducted were still in a baby condition. 
Manurung et al., (2018) explained that giant freshwater prawns can spawn throughout the year. The development of the gonad maturity occurs from July to March (the rainy season). The peak month of research was from December to February which has the highest rainfall in the rainy season, during this condition, there is a lot of freshwaters that overflows the forest vegetation on the banks of the river. This habitat is highly favorited by prawns for the spawning process. Litavia et al. (2019) informed that the gonad maturity condition of prawns is influenced by two factors, namely internal and external factors, internal factors consist of depending on the species, age, and size. Meanwhile, external factors include temperature, food availability, currents, and rainfall. (Indarjo et al., 2021; Ipandri et al., 2016) added the spawning process of giant freshwater prawns (M. rosenbergii) occurs in freshwater far from the estuary. The parents will carry their fertilized eggs to migrate downstream of the river that contains a certain level of salt to hatch eggs.

\section{CONCLUSION}

The bioecological information for the giant freshwater, giant prawns are obtain from the analysis of the growth pattern by calculating the relationship between carapace length and body weight of giant freshwater prawns found at the Bilah river.
The from the calculation it found that the growth pattern of the giant freshwater prawns was in the negative allometric category with $\mathrm{b}$ values ranging from 1.88 to 2.577. For the abundance of giant freshwater prawns based on the gonad maturity levels, they were dominated by prawns with the immature gonad category, ranging from 46.15 to $54.65 \%$.

\section{REFERENCES}

Aini, I. N., Tarsim, T., Sujatmiko, W. (2018). Perkembangan larva udang galah (Macrobrachium rosenbergii) hasil persilangan populasi Aceh dan Strain Siratu. Jurnal Teknologi Perikanan dan Kelautan, 9(1), 55-63.

Ali, F., \& Waluyo, A., (2015). Tingkat kelangsungan hidup dan pertumbuhan udang galah (Macrobrachium rosenbergii De Man) pada media bersalinitas. Jurnal Limnotek, 22(1), 42-51.

Diana, F., Kautsar, T., \& Hafinuddin, H. (2018). Pengaruh Kedalaman yang Berbeda Terhadap Hasil Tangkap Udang Galah (Macrobrachium rosenbergii) Dengan Menggunakan Alat Tangkap Bubu di Desa Cot Seumeureng Kecamatan Samatiga Kabupaten Aceh Barat. Jurnal Perikanan Tropis, 5(1), 83. https://doi.org/10.35308/jpt.v5i1.1028

Dimenta, R. (2013). Struktur Populasi dan Performa Reproduksi Udang Kelong (Penaeus indicus) di Perairan Ekosistem Mangrove Belawan Sumatera Utara, Tesis. Magister Biologi Universitas Sumatera Utara. 81 halaman.

Harahap, E. (2020). Rasio Jenis Kelamin Udang Galah (Macrobrachium rosenbergii) Pada Kondisi Perairan Sungai Barumun Kabupaten Labuhanbatu Selatan. Konservasi Hayati, 16(2), 85-91. https://doi.org/10.33369/hayati.v16i2.12472

Hargiyatno, I. T., Satria, F., \& Prasetyo, A. P. (2013). Hubungan Panjang Berat dan Faktor Kondisi Lobster Pasir (Panulirus homarus) di Perairan Yogyakarta dan Pacitan. Bawal, 5(1), 41-48.

Indarjo, A., Salim, G., Anggoro, S., Nugraeni, C., Ransangan, J., \& Firdaus, M. (2021). Bioekologi dan Bioteknologi Udang Galah (Macrobachium rosenbergii) Esturia. 
Cetakan Pertama. Banda Aceh: Syiah Kuala University Press.

Ipandri, Y., Wardiyanto, W., \& Tarsim, T. (2016). Kelangsungan Hidup dan Perkembangan Larva Udang Galah (Macrobrachium rosenbergii) Asahan Pada Salinitas Berbeda. Jurnal Rekayasa Dan Teknologi Budidaya Perairan, 5(1), 581-586.

Litavia, W., Windarti, W., \& Efawani, E. (2019). Aspek Biologi Reproduksi Udang (Macrobrachium mammilodactylus) di Rawa Sekitar Stadion Utama Riau. Jom Faperika, 6(1), 15-31.

Manurung, A. P., Yusanti, I. A., \& Haris, R. B. K. (2018). Tingkat Pertumbuhan dan Kelangsungan Hidup, Pada Pembesaran Udang Galah (Macrobrachium rosenbergii de Man 1879) Strain Siratu dan Strain GI Macro II. Jurnal Ilmu-Ilmu Perikanan Dan Budidaya Perairan, 13(1), 27-36.

Monica, S., Saputra, S., \& Solichia, A. (2017). Aspek Biologi Udang Metapenaeus conjunctus di Perairan Batang dan Kendal, Jawa Tengah. J. Maquares, 6(4), 13-14.

Permana, A., Toharudin, U., \& Suhara. (2018). Pola Distribusi Dan Kelimpahan Populasi Kelomang Laut di Pantai Sindangkerta, Kecamatan Cipatujah, Kabupaten Tasikmalaya. Jurnal Ilmu Dan Teknologi Kelautan Tropis, 10(1), 87-98. https://doi.org/10.29244/jitkt.vioi1.16334

Pratiwi, I., \& Dimenta, R. H. (2021). Populasi Kepiting Bakau (Scylla serrata) di Perairan Muara Sungai Barumun Kabupaten Labuhanbatu Ditinjau dari Pola Pertumbuhan dan Faktor Kondisi. Bioscientist : Jurnal Ilmiah Biologi, 9(1), 209222.

https://doi.org/https://doi.org/10.33394/bji b.v9i1.3749

Safitri, A., Sari, S., \& Kurniawan, A. (2019). Kematangan Gonad Udang Galah Macrobrachium rosenbergii Dengan Pakan Alami Yang Berbeda, Jurnal Aquakultur, 4(2), 10-15.

Seiyaboh, E. I., Izah, S.C., \& Okogbue, B.C. (2016). Seasonal Variation in Length-Weight Relationship and Condition Factor of Five
Fish Species from Kolo Creek, Niger Delta. Greener Journal of Agricultural Sci, 6(11), 342348.

http://doi.org/10.1558o/GJAS.2016.11.12191621 6.

Simon, K. Das, De, M., \& Mazlan, A. G. (2014). Length-Weight Relationship and Trophic Level of Hard-Tail scad Megalaspis cordyla. Science Asia, 40(5), 317-322. https://doi.org/10.2306/scienceasia15131874.2014.40.317

Sofian, S., \& Sari, Y. P. (2018). Kajian Terhadap Pola Pertumbuhan Udang Galah (Macrobrachium rosenbergii) di Sungai Ogan Sumatera Selatan. J. Fishtech, 7(2), 120-123. https://doi.org/10.36706/fishtech.v7i2.6841

Suwartiningsih, N., \& Utami, L. (2020). Variasi Morfologis Induk Udang Galah (Macrobrachium rosenbergii de Man, 1879) Populasi Siratu, GI Macro , Mahakam , dan Bengawan Solo. Depik Jurnal Ilmu-Ilmu Perairan, Pesisir dan Perikanan, 9(2), 220226. https://doi.org/10.1317o/depik.9.2.15963 Syatriawan, D., Anggraini Yusanti, I., \& Anwar, S. (2019). Pembesaran Udang Galah (Macrobrachium rosenbergii de Man) Dengan Sistem Monoseks dan Campuran Terhadap Pertumbuhan, Kelangsungan Hidup, dan FCR. Jurnal Ilmu-Ilmu Perikanan Dan Budidaya Perairan, 14(1), 30-36. https://doi.org/10.31851/jipbp.v14i1.3371

Wahyudi, M. J., \& Fadlil, A. (2013). Sistem Pakar Untuk Mengidentifikasi Penyakit Udang Galah Dengan Metode Theorema Bayes. Jurnal Sarjana Teknik Informatika, 1(1), 11-20. https://doi.org/10.12928/jstie.vii1.2500

Waluyo, A., Mulyana, M., \& Ali, F. (2019). Tingkat Kelangsungan Hidup Dan Pertumbuhan Udang Galah (Macrobrachium Rosenbergii De Man) Pada Media Bersalinitas. Jurnal Mina Sains, 4(2), 107-126. https://doi.org/10.30997/jms.v4i2.1553

Wijaya, Y., \& Muchtar, H. (2019). Kesadaran masyarakat terhadap kebersihan lingkungan sungai. Journal of Civic Education, 2(5), 405411. https://doi.org/10.24036/jce.v2i5.297 